\title{
BAS JAN ADER'S LUDIC CONCEPTUALISM: PERFORMING A TRANSNATIONAL IDENTITY
}

\author{
Janna Schoenberger \\ University of Amsterdam
}

Profa. Dra. Janna Schoenberger atua como professora da University of Amsterdam. Concluiu seu PhD no Graduate Center, na City University of New York com a tese Ludic Conceptualism: Art and Play na Holanda de 1959 a 1975." Recentemente, Dra. Schoenberger concluiu bolsas no Rijksmuseum e na Biblioteca Beinecke da Universidade de Yale. Seu livro, Waiting for the Witch Doctor: Robert Jasper Grootveld's Scrapbook and the Dutch Counterculture, foi publicado pelo Rijksmuseum em 2020. Este artigo foi publicado originalmente pela John Benjamins Publishing Company no ano de 2015.

\footnotetext{
Abstract: Following Huizinga's ideas in his Homo Ludens (1938), I propose the term Ludic Conceptualism to describe the art that flourished in the Netherlands from 1959 to 1975 . Unlike the more severe strands of conceptualism developed in New York and the United Kingdom, play was central to its Dutch incarnation. In this chapter I will show how Dutch conceptual artist Bas Jan Ader's fixation on his identity, as staged through satirical jokes based on national stereotypes, is key in understanding his art. While a great deal of the humor is obvious in Ader's work, there has been no serious inquiry into his comedic practice. I will position Ader within the framework of post-war humorous conceptual art prevalente both in the Netherlands and California, locales in which Ader had lived and studied. Using theories of humor and identity I will demonstrate how Ader's jokes are closely tied to social contexts on both sides of the Atlantic, environments relevant to the artist's development in the course of his short career. A close examination of Ader's work will reveal that the artist's blurred identity as seen in his use of humor is, in fact, a central feature of his art.
} 

zen observed, used too many English words and spoke his Gronings dialect with an American accent. The reporter concluded that the artist's time in the United States had caused him to become arrogant, a claim connected to Ader's alleged difficulty speaking Dutch. Ader was quoted as saying (perhaps at the encouragement of the interviewer): "I'm not a Groninger nor Dutch, but I'm also not an American. I don't want to be anything than Bas Jan - myself" (Nahuizen 1961).

Who was Bas Jan Ader? His blurred identity, re"ected in his use of humour, is, in fact, a central feature of his work. Specifically, in this chapter, I will show how understanding Ader's fixation on his cross-cultural identity, as staged through satires of national stereotypes and tropes, is vital to understanding his art.

There has to date been no serious inquiry into the comedic aspect of Ader's practice. Writing on Ader has instead focused on the tragic, specifically the execution of his father during World War II and Bas Jan's mysterious death at sea in 1975. Ader has been placed in a tradition of melancholic Romanticism, in company with figures such as Caspar David Friedrich (Verwoert 2006; Sefermann et al. 2008). I argue, instead, that Ader should be positioned within the framework of post-war humorous conceptual art that was prevalent both in the Netherlands and California, places where he lived and studied. I will explore how the use of humour developed on the West Coast from its position at the periphery of the art world and why the Netherlands was particularly receptive to ludic art. Using theories of humor and identity, I will show how Ader's jokes are closely tied to social contexts on both sides of the Atlantic, environments relevant to the artist's development over the course of his short career.

In one of his most renowned books, Homo Ludens: A Study of the Play-Element in Culture, first published in 1938, Dutch cultural historian Johan Huizinga argued that play is the formative element of culture and is present in nearly all cultural expressions (1971). ${ }^{2}$ A linguist at heart, Huizinga found that the best word to describe childlike, inquisitive, and inherently moral play was the Latin ludus, hence the title of his book. ${ }^{3}$ Following Huizinga, I use the term "ludic" to describe the trend of playful art that was popular in both the Netherlands and the West Coast of the United States in the 1960's and early 1970's. Unlike the more severe, bureaucratic, and tautological strands of conceptualism that developed in New York (such as that of Joseph Kosuth), humour is central in the Netherlands and California. I propose ludic conceptualism as the most appropriate term to describe the art made by Bas Jan Ader and others in this vein.

Humour pervaded art created and exhibited at Dutch institutions in the sixties. An affection for playfulness connects a variety of designs, photographs, films and performances. For example, Constant Nieuwenhuis's New Babylon, a plan for a utopian city as a never-ending playground, was first exhibited in Amsterdam in 1959. In this proposed city, citizens would not be obliged to work but instead could live as creative beings; that is, their existence and meaning could be found in their anti-rational, anti-func-

2 The widely available English translation is a synthesis of Huizinga's 1944 German and English translations. In the 'Foreword' Huizinga clarifies that the subtitle should read "The Play Element of Culture", but the unidentified translator explained that "The Play Element in Culture" was "more euphonious".

3 For the most recent study on Huizinga and his work, see Willem Otterspeer, Reading Huizinga, trans. Beverley Jackson (Amsterdam University Press, 2011). The title Homo Ludens, man the player, is a direct response to Marxism the importance of homo farber, man the maker, Huizinga argued that the weight given to economic forces in the course of the world by Marxists was a "shameful misconception." Huizinga, Homo Ludens, 192. 
tional contributions to society. Two years later, Wim T. Schippers staged a performance of emptying a bottle of soda into the sea, which was broadcast on television. In a series of works executed in 1961, artist Stanley Brouwn proposed a new method of constructing maps that would better reflect a person's subjective experience of navigating the city: This Way Brouwn, No Way Brouwn, Brouwn this Way Public, and This Way Brouwn for the Soul, all of which involve pedestrians drawing directions to places in Amsterdam that may or may not exist.

The Dutch were not alone in their embrace of humour: California also produced a wave of ludic art in this period, especially in conceptualism. It is no surprise, therefore, that California conceptual artists, including John Baldessari and Allen Ruppersberg, were well received in the Netherlands: both had early solo exhibitions in Amsterdam in 1972 and 1973, respectively. Humour was a popular mode of expression in Los Angeles in part due to the presence of the entertainment industry and in part due to the relative lack of critical media, especially compared to New York (Baldessari 2011). ${ }^{4}$ According to L.A. native and former director of the Stedelijk Museum Amsterdam, Ann Goldstein, since entertainment was the city's main focus, L.A. was a great place to be an artist because "no one cared about you" (Larry Bell and Ann Goldstein 2013). In New York, artists could be certain that each artwork or statement would be closely examined and analyzed, leading to a ponderous self-seriousness on the part of the art community. In Los Angeles, by contrast, a lack of critical attention allowed artists the freedom to play (Baldessari 2011). ${ }^{5}$

4 John Baldessari, in conversation with Ann Goldstein and Rudi Fuchs, tried to articulate why humor was a driving force.

5 In the same conversation Rudi Fuchs commented on the humor he enjoyed in the work of Baldessari, Bruce Nauman,
Why were museums and galleries in the Netherlands so receptive to ludic conceptualism, especially that coming out of Los Angeles, and why was humorous conceptual art so widespread in the Netherlands? As L.A. stood in relation to New York, so Amsterdam occupied a peripheral position with regard to the art powerhouse of Paris. Humour was a central critical strategy not only for Dutch artists but also for Dutch political activists, who made use of satire's potential to provoke in order to question the current social order. In the mid-sixties, the Provo anarchist movement tried to address traffic and congestion in the city by advocating the distribution of free, white-painted bicycles throughout Amsterdam, which became known as the "white-bicycle plan." The Provos used a series of provocative ludic tactics to confront both the conservative Dutch government and the largely conformist middle-class population - for example, in order to bring attention to the way Amsterdam catered to cars as opposed to cyclists and pedestrians, they handed out currants in the middle of the street to disrupt traffic. In the tradition of satirical humour, the Provos mocked social conventions, and in this instance they expressed frustration with the burgeoning car culture in Amsterdam. Finally, Dutch artists were tapping into a long tradition of humour and satire in art and literature, traceable as far back as the late fifteenth century; one need only think of the artist Hieronymus Bosch and the humanist scholar Erasmus's In Praise of Folly, among many other examples. Ader was thus part of a generational embrace of humour and satire in Dutch and American artistic practices.

It is fruitful to examine the satirical nature of Ader's work through the lens of incongruity the-

and Sol LeWitt, who is well represented at the Stedelijk Museum Amsterdam. Fuchs referred to LeWitt as a "comic master." 
ory. According to this theory, currently dominant in humour studies, humour is found in a thing or event that violates mental patterns or expectations (Morreall 2009). Philosopher Simon Critchley further posits that there is an implicit social contract between the joke teller and the audience, because in order to understand incongruence there must first be congruence. If congruence is missing, then the joke won't be funny (Critchley 2002: 4). This explains, for example, why it is so hard to tell a joke in a foreign language: humour tends to be local, context-specific, and a form of insider knowledge (ibid.: 67). According to Critchley, "The sweet melancholy of exile is o0en rooted in a nostalgia for a lost sense of humour" (ibid.: 68). He adds that the humour that brings us back to a home or to what we know o0en does so by relating joint anxiety, difficulty, and shame (ibid.: 74). Satire only functions with a common cultural base, or congruence, and the humour in satire exists in the attack of those shared beliefs.

As a Dutch immigrant in Southern California, Bas Jan Ader used humour to express the struggle of living between two nations: his mother country and his chosen home in the United States. Ader, in a satirical manner, drew upon clichés and stereotypes from both nations for his drawings, films, and photographs. In his use of satire, Ader looked to his own background and identity as source material to question social norms. His artist's book - published in conjunction with his Master of Fine Arts graduation exhibition at Claremont Graduate School and the University in California in February 1967 - is larded with puns that only his fellow Dutchmen were likely to catch. For example, he wrote and illustrated a short story for the book entitled "What makes me so pure, almost holy? And more," about the adventures of a Dutch boy with his friend Béa - a nickname for then
-Princess (and up until recently Queen) Béatrix - who, among other things, try to move a weighty throne. In the image opposite the first page, the name Béa Bloemkool is inscribed over an abstracted map of the Netherlands. In addition to the humorous alliteration, the name (bloemkool means cauliflower) alludes jokingly to Ader's native rural province of Groningen, where cauliflower is a typical crop and a common ingredient in traditional dishes. Probably not coincidentally, bloemkool was also a crude slang term for breasts. (Its most well-known use is in Dutch comedian and songwriter André van Duin's 1979 hit, "'k Heb Hele Grote Bloemkolen" [I have very large cauliflowers].) Even though Ader wrote his short story in English, he chose a Dutch word to alliterate Béa's name; and not just any Dutch word, but one that harks back to his hometown's rather sexist humour. Ader also visually called out his local region with a star above Groningen on his map of the Netherlands. It's worth asking: who would get the joke? Notably, his fellow Dutch exile and friend Ger van Elk must have been a part of Ader's designated audience (Daalder 2008). Ader's use of the site-specific humour local to the northern Netherlands indicates a certain nostalgia and longing for his native province.

In a poem in the same artist's book, "What does it mean? Cheep cheep?," Ader further articulates his homesickness. On the bottom of the first page, Ader explains that the poem is about "today and yesterday," meaning his life between California and the Netherlands. Ader was seemingly happy with his wooden house and American wife in L.A., where he apparently fit in, but he missed the Dutch brick houses and noted "the grass was greener on the other side." In this book, we can see Ader, writing as an expatriate in California, veiling his homesickness with a humour rooted in the Netherlands. 


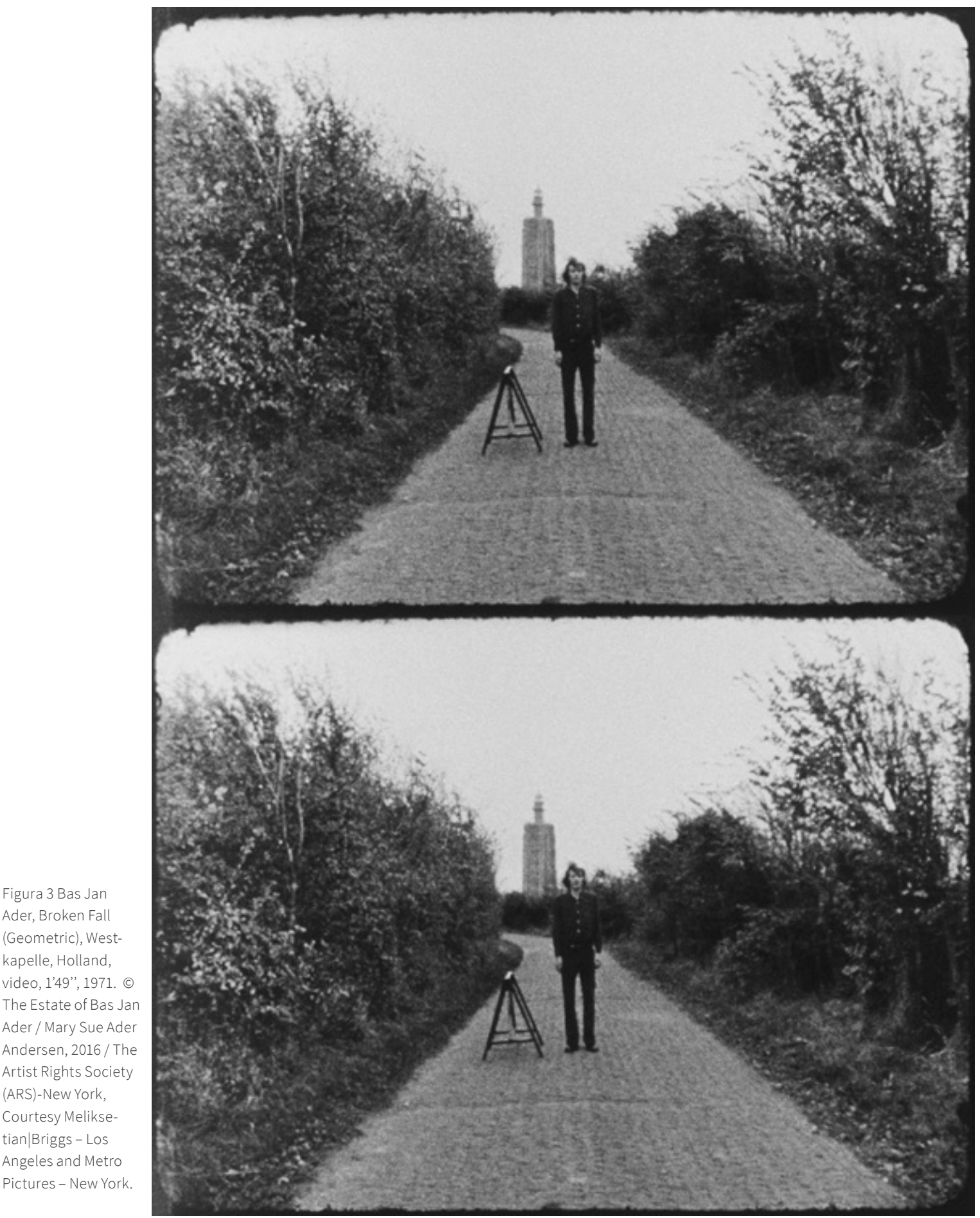



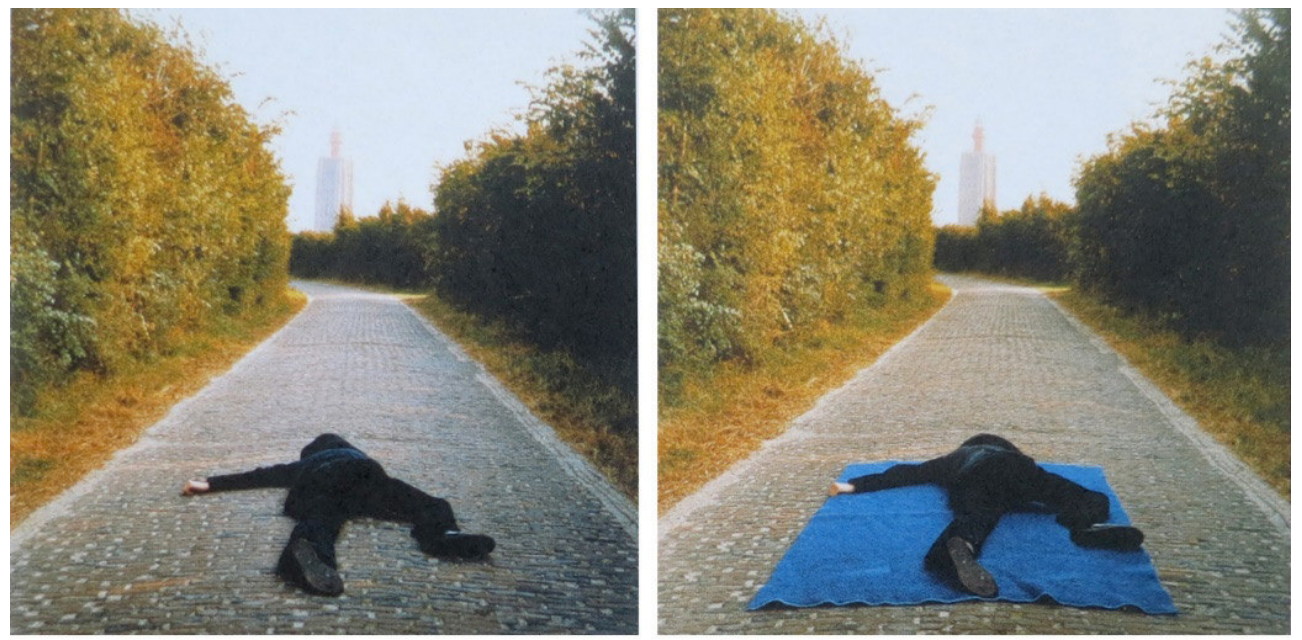

Figura 4 Bas Jan Ader, On The Road to a New Neo Plasticism, Westkapelle, Holland, 1971, four c-type prints, each $30 \times 30 \mathrm{~cm}$. (c) The Estate of Bas Jan Ader / Mary Sue Ader Andersen, 2016 / The Artist Rights Society (ARS)-New York, Courtesy Meliksetian|Briggs - Los Angeles and Metro Pictures - New York.
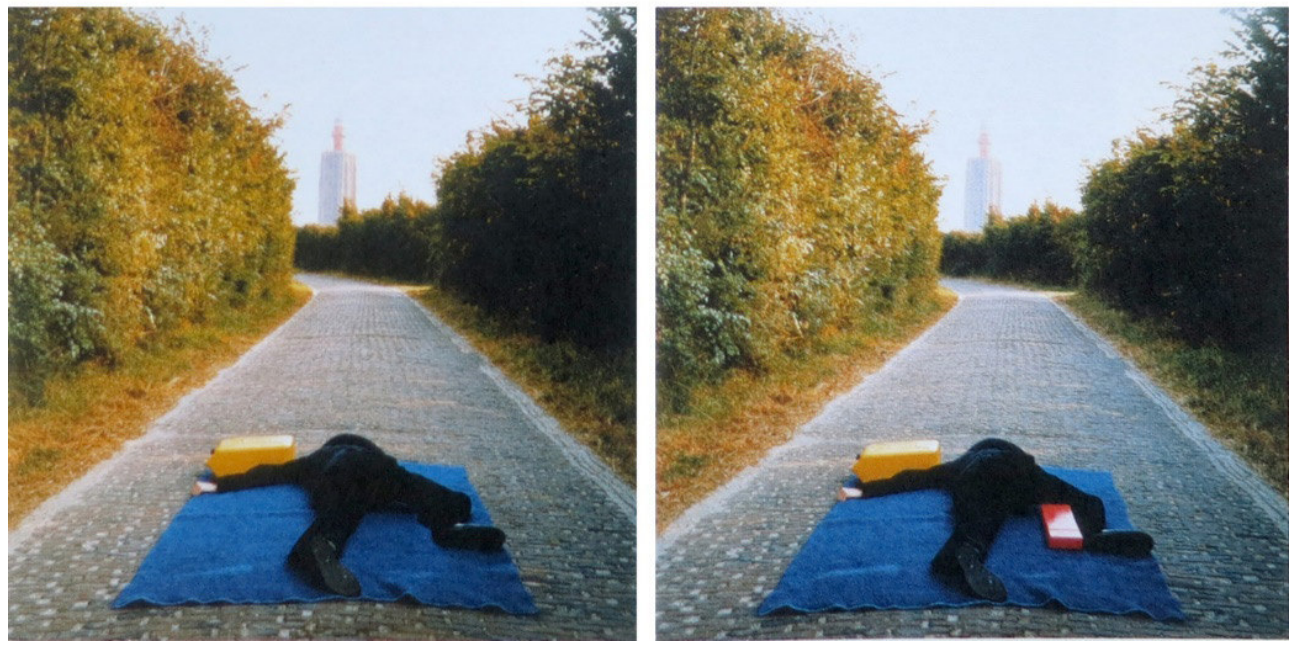

(Amsterdam), Ader here incorporated California slapstick into a typical Dutch landscape. Ader's work can thus be viewed as a self-portrait, embodying and performing his bi-national identity.

Whereas the film Broken Fall (Geometric) is a conceptual nod to De Stijl, his On the Road to a New Neo Plasticism, Westkapelle Holland from 1971 can be seen as a formal citation of the De Stijl movement. In this series of four photographs, Ader physically built himself into an abstracted De Stijl composition by becoming black vertical and horizontal lines and sequen-

tially adding primary-coloured objects to form a translation of a Piet Mondrian painting. Perhaps we can read On the Road as a contemporary interpretation of a tableau vivant. A further exploration of primary colours with a reference to Dutch art is the video Primary Time (1974), ${ }^{6}$ in which Ader gradually rearranges a vase of flowers so that the assortment changes from entirely red to yellow and finally to blue. Again, Ader is com-

6 Primary Time is a video from 1974 and was made at the same time as Untitled (Flower work), a series of photographs from the same year. 


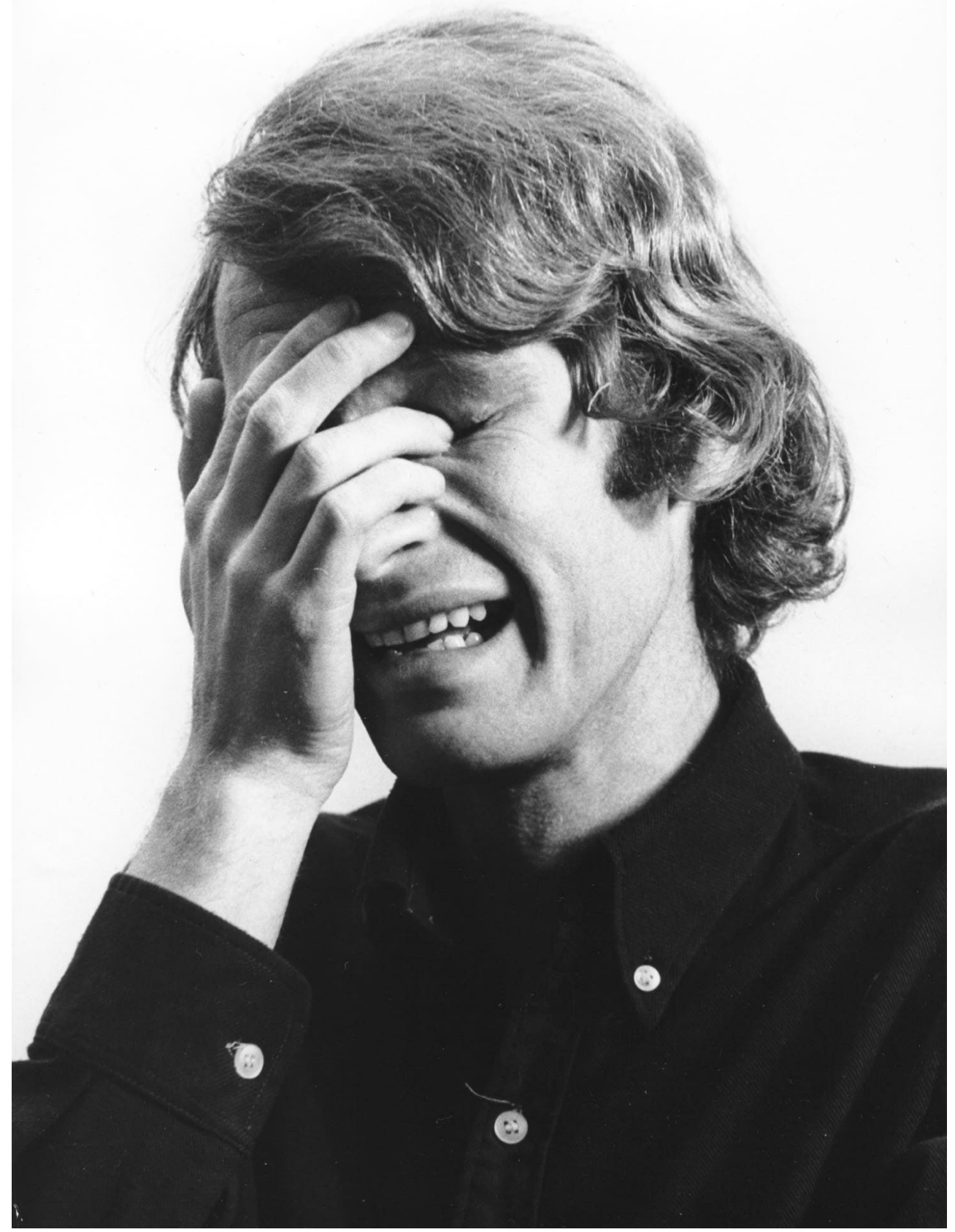

Figura 5 Bas Jan Ader, I'm Too Sad to Tell You, video 16mm, 3'21", 1971. ( The Estate of Bas Jan Ader / Mary Sue Ader Andersen, 2017 / The Artists Rights Society (ARS), New York. Courtesy of Meliksetian | Briggs, Los Angeles. 
bining Dutch tropes - in this case, flowers - with a dry comic sensibility.

Not all of Ader's works are as amusing as the Fall films, but the humour in much of his art has been underrated. I'm Too Sad to Tell You was the title of three separate works that took on the same theme and imagery: the first was a photograph in 1970; the second a postcard sent to his friends and acquaintances later that year; and the third a three-minute film shot in 1971. Thematically, I'm Too Sad to Tell You is arguably his least funny work. All the pieces show a close-up, cropped image of Ader shedding tears for no apparent reason. Ader described the film version as another one of his Fall films, yet it is tears that obey the force of gravity this time instead of the artist's body (Van Garrel 1972: 48). In 1972, Ader explained that the work was his reaction to the "he-man" culture of California (ibid.: 49). Could this be the culture shock of a Dutch foreigner abroad? Maybe I'm Too Sad to Tell You has more humour than appears at first glance. The satire here can be found in Ader playing with and inverting the extreme masculinity he encountered in California.

Certainly, his premature death, which occurred as he was completing In Search of the Miraculous, has cast such a pall over his earlier works that scholars have failed to take Ader's humour seriously. In Search of the Miraculous names a series of 18 photographs from 1973, documenting a night-time walk from the freeway to the sea in Los Angeles. ${ }^{7}$ Along the bottom of the photographs, Ader has written the lyrics to the Coasters' 1957 song "Searchin'." The 1975 version of In Search was composed of three parts, beginning with an exhibition at the Claire Copley Gallery in Los Angeles. On opening night, Ader's students from the University of California, Irvine, sang a

7 There is also a version of the work with 14 photographs. series of sea shanties that were recorded and later played throughout the duration of the exhibition. Ader was to continue the journey with a voyage across the Atlantic Ocean, alone in a twelve-and-a-half-foot sailboat - a feat that, had it been successful, would have broken a world record. The concluding element was to have been an exhibition at the Groninger Museum, intended to include photographs of a night walk in Amsterdam to mirror the L.A. images. Some weeks after Ader left from Cape Cod, however, radio contact was lost; the remains of his boat were found of the coast of Ireland four months later (Roberts 1994: 32-35). Critics have focused on Ader's death and have even suggested the possibility of suicide (Verwoert 2006: 47). In his book on In Search, Jan Verwoert wrote, "In the end, through his disappearance and death, Ader came to embody this role of the romantic tragic hero in an unexpected and irrevocable way. The work is about the idea of the tragic and is itself a tragedy" (2006: 8) - the artwork became his death and ceased to be an artwork. I propose instead to view In Search of the Miraculous as a continuation of his artistic practice: in his use of dry humour, which is evident in the night-walk photographs; in the questions of satirical transnational humour in the entire three-part plan; and in the artist personally carrying out the work, casting himself as a sailor in the Dutch nautical tradition.

\section{Conclusion}

I have positioned Ader within the framework of post-war humorous conceptual art prevalent both in the Netherlands and California, locales in which he has lived and studied. Using theories of humor and identity I have demonstrated how his jokes are closely tied to social contexts on both sides of the Atlantic and argued that the artist's blurred identity as seen in his use of 
from Grace with the Sea." Frieze 17(August):

32-35.

SCHORR, Collier. 1994. "This Side of Paradise." Frieze (August): 35-37.

SEFERMANN, Ellen, Jorg Heiser and Susan Hiller. 2008. Romantic Conceptualism. Bilingual Edition. Bielefeld: Kerber.

STEENBERGEN, R. 1993. "Bas Jan Ader." NRC Handelsblad, March 5.

TIMMERMAN, Els. 1993. "Op zoek naar het wonder." HP De Tijd, July 9.

VERWOERT, Jan. 2006. Bas Jan Ader: In Search of the Miraculous. London: Afterall Publishing. WOLFE, Charles. 2010. "California Slapstick Revisited." In Slapstick Comedy, ed. by Tom Paulus and Rob King, 169-190. New York: Routledge. 